\title{
A new technical approach for preparing frozen biological samples for electron microscopy
}

\author{
Othmar Buchner ${ }^{1 * \dagger}$, Philip Steiner ${ }^{1 \dagger}$, Ancuela Andosch¹, Andreas Holzinger ${ }^{2}$, Matthias Stegner ${ }^{2}$, \\ Gilbert Neuner ${ }^{2}$ and Ursula Lütz-Meindl ${ }^{1}$
}

\begin{abstract}
Background: Many methodological approaches have focused so far on physiological and molecular responses of plant tissues to freezing but only little knowledge is available on the consequences of extracellular ice-formation on cellular ultrastructure that underlies physiological reactions. In this context, the preservation of a defined frozen state during the entire fixation procedure is an essential prerequisite. However, current techniques are not able to fix frozen plant tissues for transmission electron microscopy (TEM) without interrupting the cold chain. Chemical fixation by glutaraldehyde and osmium tetroxide is not possible at sub-zero temperatures. Cryo-fixation methods, such as high pressure freeze fixation (HPF) representing the state-of-the-art technique for best structural preservation, are not equipped for freezing frozen samples. In order to overcome this obstacle, a novel technical approach for maintaining the cold chain of already frozen plant samples prior and during HPF is presented.
\end{abstract}

Results: Different algae (Micrasterias denticulata, Klebsormidium crenulatum) and higher plant tissues (Lemna sp., Ranunculus glacialis, Pinus mugo) were successfully frozen and prepared for HPF at freezing temperatures $\left(-2^{\circ} \mathrm{C}\right.$, $-5^{\circ} \mathrm{C},-6^{\circ} \mathrm{C}$ ) within a newly developed automatic freezing unit (AFU), that we manufactured from a standard laboratory freezer. Preceding tests on photosynthetic electron transport and ability to plasmolyse show that the temperatures applied did not impair electron transport in PSII nor cell vitality. The transfer of the frozen specimen from the AFU into the HPF-device and subsequently cryo-fixation were performed without intermediate thawing. After cryo-substitution and further processing, the resulting TEM-micrographs showed excellent ultrastructure preservation of the different organisms when compared to specimens fixed at ambient temperature.

Conclusions: The method presented allows preserving the ultrastructure of plant cells in the frozen state during cryo-fixation. The resulting high quality TEM-images represent an important step towards a better understanding of the consequences of extracellular ice formation on cellular ultrastructure. It has the potential to provide new insights into changes of organelle structure, identification of intracellular injuries during ice formation and may help to understand freezing and thawing processes in plant tissues. It may be combined with analytical TEM such as electron energy loss spectroscopy (EELS), X-ray analyses (EDX) and various other electron microscopic techniques.

Keywords: Cell organelles, High pressure freeze fixation, Klebsormidium crenulatum, Lemna sp., Micrasterias denticulata, Pinus mugo, Ranunculus glacialis, Transmission electron microscopy, Ultrastructure

\footnotetext{
*Correspondence: mail@o.buchner.co.uk

${ }^{\dagger}$ Othmar Buchner and Philip Steiner are joint first authors

1 Department of Biosciences, University of Salzburg, Hellbrunnerstrasse

34, 5020 Salzburg, Austria

Full list of author information is available at the end of the article
}

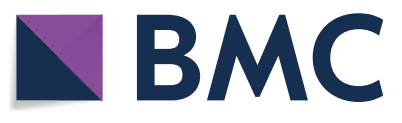

(c) The Author(s) 2020. This article is licensed under a Creative Commons Attribution 4.0 International License, which permits use, sharing, adaptation, distribution and reproduction in any medium or format, as long as you give appropriate credit to the original author(s) and the source, provide a link to the Creative Commons licence, and indicate if changes were made. The images or other third party material in this article are included in the article's Creative Commons licence, unless indicated otherwise in a credit line to the material. If material is not included in the article's Creative Commons licence and your intended use is not permitted by statutory regulation or exceeds the permitted use, you will need to obtain permission directly from the copyright holder. To view a copy of this licence, visit http://creativeco mmons.org/licenses/by/4.0/. The Creative Commons Public Domain Dedication waiver (http://creativecommons.org/publicdomain/ zero/1.0/) applies to the data made available in this article, unless otherwise stated in a credit line to the data. 


\section{Background}

The occurrence of freezing temperatures is one of the major environmental constraints limiting plant productivity and distribution [1]. A key point for survival of freezing temperatures is the tolerance of ice formation within the plant tissue that generally represents a dramatic incident. Extracellular ice, besides the mechanical impact, may expose plant cells to significant freeze dehydration [2]. Plants have evolved different strategies to cope with these freezing specific strain, such as freezing avoidance $[3,4]$ and freezing tolerance (reviewed by $[5$, 6]).

Since Levitt [7] there is a general agreement that ice, once it is formed intracellularly always causes cell death. In contrast, ice which is formed outside the cell wall (extracellularly) can principally be survived down to certain freezing temperature thresholds [1]. However, the causes of freezing injury to cells, the nature and cellular loci, are still unknown [8].

Extracellular ice causes a steep water potential gradient between the ice bulk outside the cells and the cell sap that consists of a supercooled highly diluted aqueous solution. The water potential of ice is much lower than that of unfrozen (supercooled) water at a specific freezing temperature and this water potential gradient becomes steeper with decreasing temperature $[9,10]$.

At slow cooling rates and due to the water potential gradient between ice and unfrozen water a certain amount of water will be withdrawn from the cell to the ice bulk resulting in cellular freeze dehydration [11] provided that the cell wall is not too rigid and allows cell volume reduction [12]. In the course of this, cells with thin and elastic cell walls can undergo massive but not necessarily lethal freezing cytorrhysis within a few seconds as was demonstrated in Sphagnum capillifolium leaflets [13].

While through the last decades many elucidating studies on freezing behaviour and freezing tolerance of plants have been performed (see $[1,6,14-16]$ ), only little is known on the consequences of extracellular ice formation on a cellular and sub-cellular level (e.g. [1, 17-19]). The effects of non-lethal extracellular ice-formation on plastids and mitochondria as well as on the endoplasmic reticulum and the Golgi-apparatus is widely unexplored.

For studying the cellular and subcellular responses to extracellularly freezing, and for gaining meaningful insights into mechanisms of freeze-thaw injury, the high resolution of TEM is required for the visualisation of cell membranes and cell organelles. As the current tools and techniques have been insufficient for preparing extracellularly frozen plant tissues for TEM, novel techniques have to be introduced.
As chemical fixation by glutaraldehyde (GA) and osmium tetroxide $\left(\mathrm{OsO}_{4}\right)$ is not possible at freezing temperatures, a combination of cryofixation such as HPF or plunge freezing followed by cryo-substitution is the only possibility for preparation of frozen biological samples for TEM. The application of plunge freezing is limited to very small samples. Therefore, we have chosen HPF for the present investigation which is still state of the art in respect to structure preservation [20-28].

During HPF, cell suspensions or small tissue samples are exposed to high pressure (up to $>200 \mathrm{MPa}$ ) and almost simultaneously to rapidly $\left(>10000{ }^{\circ} \mathrm{C}^{\prime} \mathrm{s}^{-1}\right)$ cooling down to the temperature of liquid nitrogen $\left(\mathrm{LN}_{2}\right.$, $-196^{\circ} \mathrm{C}$ ). This procedure causes the vitrification of the liquid water within and outside the cells. Despite outstanding issues [29], the principle of vitrification is also widely used in cryo-preservation and means that the water is directly transformed to a "glassy state" without forming ice crystals [30-33]. However, to our knowledge HPF was never applied to monitor frozen plant cells and tissues, and presently it is not fully clear what will happen to already formed ice (Ice Ih, hexagonal ice) when exposed to such high pressure and cooling rates. Principally, it is conceivable that under such conditions Ice Ih could be replaced by other types of ice (e.g. Ice II, Ice III) which have different crystal structures and physical properties, e.g. with regard to specific density $[34,35]$. This could be relevant because transformations of the crystal structure of ice were shown to have the potential for disrupting cell structure [36].

The required technical approach for obtaining TEMimages of already frozen plant cells after HPF fixation is to keep frozen plant samples in a defined frozen state during preparation and fixation. Thawing of the samples during preparation and fixation must be strictly avoided. Hence, an important aim of this study was to develop a temperature controlled preparation technique including the insertion into the HPF-device. Such a tool is currently not available to our knowledge.

Our newly developed method was tested on four well known model organisms that have been widely studied by TEM before: Micrasterias denticulata, an unicellular freshwater alga (reviewed by [37]), Klebsormidium crenulatum, a filamentous aeroterrestrial green alga [38, 39], Lemna sp., a floating macrophyte [40-42], and the high alpine higher plant species Ranunculus glacialis [43, 44]. Additionally, needles from Pinus mugo, a coniferous shrub from the sub-alpine/alpine knee timber zone, were investigated.

We hypothesized that it should be possible to develop a novel technique to (1) keep frozen cells during the whole process of preparation and fixation by HPF in the frozen state. This must be considered as a prerequisite 
for analysis of the structural changes of cells, membranes and cell organelles while being exposed to extracellular ice. And further, after HPF fixation, without knowledge of the fate of extracellular ice during HPF, (2) we expected that these samples should provide good structural preservation of extracellularly frozen cells for TEM.

\section{Results \\ Sample temperature \\ Temperature during the controlled freezing exposure prior to HPF}

During the experimental freezing exposure within an automatic freezing unit (AFU) that was newly developed by modifying a standard laboratory freezer, the leaf temperatures and the temperatures of the samples followed the preset-temperature course with high accuracy. The freezing experiments were started at temperatures between $0{ }^{\circ} \mathrm{C}$ and $+4{ }^{\circ} \mathrm{C}$. During the cooling phase down to the target freezing temperatures $(M$. denticulata, $K$. crenulatum and Lemna sp.: $-2{ }^{\circ} \mathrm{C}, R$. glacialis: $-5{ }^{\circ} \mathrm{C}, P$. mugo: $-6{ }^{\circ} \mathrm{C}$ ) temperature deviations occurred with maximum $\pm 0.1{ }^{\circ} \mathrm{C}$ ( $M$. denticulata, $K$. crenulatum), $\pm 0.4{ }^{\circ} \mathrm{C}$ (Lemna sp.) and $\pm 0.5{ }^{\circ} \mathrm{C}$ (R. glacialis). In case of $P$. mugo the maximum temperature deviations were temporarily higher $\left( \pm 1.1{ }^{\circ} \mathrm{C}\right)$ due to technical reasons (temporary stabilisation at $-2{ }^{\circ} \mathrm{C}$ and working inside the AFU). Deviations of the sample temperature occurred also during sample preparation at target freezing temperatures, mainly when inserting and retracting the hands into/from the AFU. However, these deviations (typ. $< \pm 1{ }^{\circ} \mathrm{C}$ ) were only transient and did never lead to thawing of the samples (Fig. 1).

\section{Temperature during transportation of the frozen samples to the HPF-device}

A typical temperature course of a frozen sample $\left(-5^{\circ} \mathrm{C}\right)$ during transportation from the AFU to the HPF-device and during HPF as measured by the temperature measurement adapter (TMA) is presented in Fig. 2.

Transport from the freezer to the HPF-device led to a slight but neglectable change of the sample temperature $\left(-0.2^{\circ} \mathrm{C}\right)$. This was possible as transportation of the samples took place inside of a precooled metallic transfer block which was positioned inside the AFU during freezing and sample preparation. The transfer block effectively shielded the sample from the high ambient air temperature during transportation. By strictly following the protocol (see Table 1), also the next preparation steps, did not lead to significant temperature increases until HPF was started.

When the loading device with the sample was pulled out from the metallic transfer block and positioned on

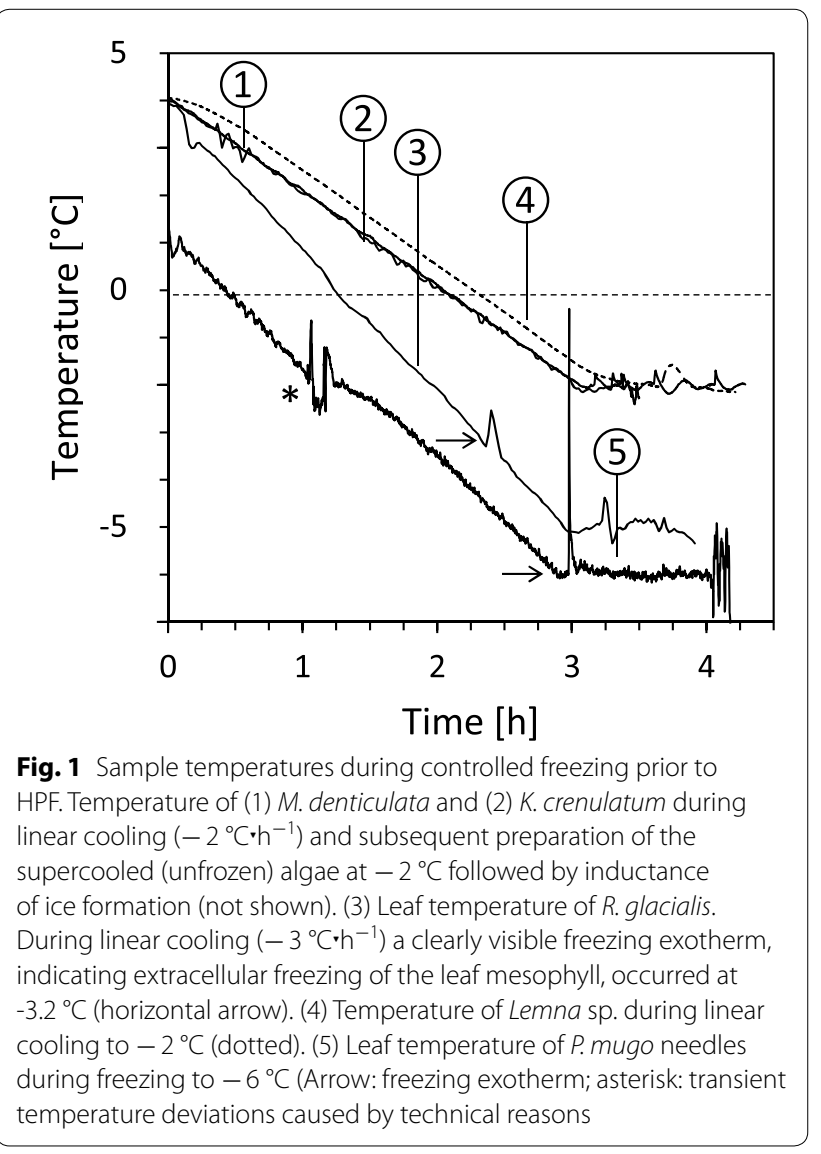

the moveable loading arm of the HPF-device, the sample temperature temporarily increased to $-3.8{ }^{\circ} \mathrm{C}$ and stabilized again at $-5.2{ }^{\circ} \mathrm{C}$ within $3 \mathrm{~s}$. During inserting the loading device into the HPF-device, locking and starting HPF, the sample temperature again temporarily increased to $-4.2{ }^{\circ} \mathrm{C}$ before it fell down to $-196{ }^{\circ} \mathrm{C}$ during rapid fixation by HPF. In contrast, the temperature of a frozen sample increased rapidly already during sliding in by ca. $+10^{\circ} \mathrm{C}$ and by further $+15^{\circ} \mathrm{C}$ after locking the loading device, when precooling by the precooling device (PD) was not performed. It is worth noting that the temperature which is displayed and stored by the HPF-device may differ significantly from the real sample temperature as being measured by the TMA.

\section{Structural preservation of HPF frozen samples in TEM}

By means of preceding vitality tests based on cell plasmolysis and on in vivo chlorophyll fluorescence combined with the visual assessment of freezing damage [45], the actual freezing resistance of the samples was determined. This was absolutely necessary for choosing temperature regimes (cooling rates, target temperatures, duration of exposure) to the samples that were not expected to cause visible frost damage to the plants examined. 


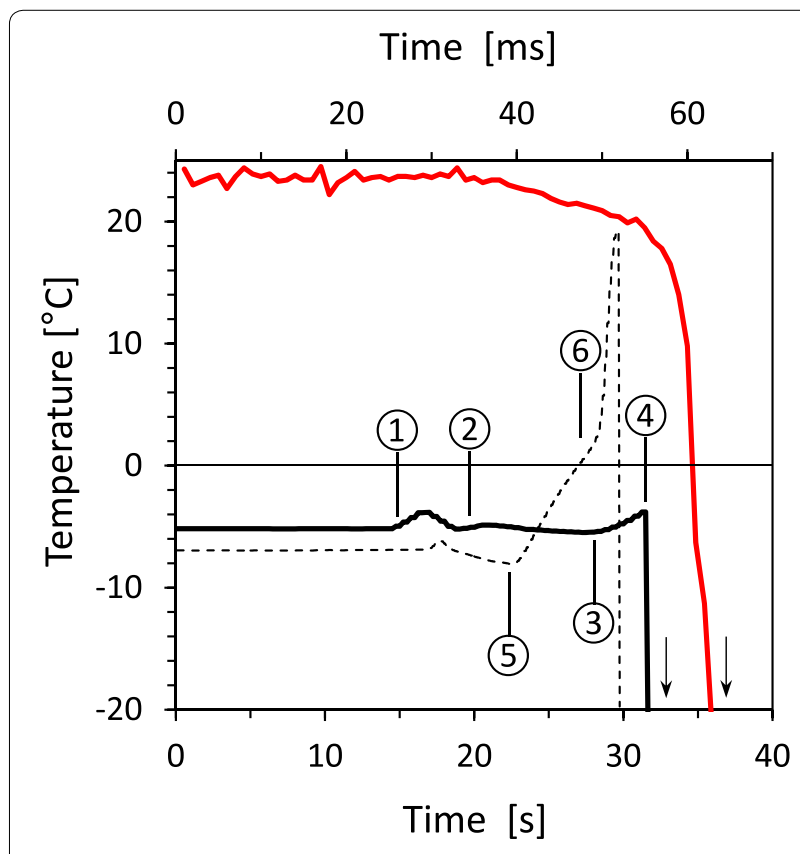

Fig. 2 Typical temperature courses prior to and during high pressure freezing (HPF) of frozen samples. Data as generated during cryofixation by the HPF-device (red line, upper $x$-axes) and data based on direct measurements of the sample temperature using the temperature measurement adapter (TMA, black lines, lower $x$-axes), are compared. Solid black line: The frozen samples were transferred to the HPF-device within a precooled transfer block (0 to $15 \mathrm{~s}$ ) to prevent thawing. When the loading device with the frozen sample was pulled out of the transfer block (1) short intermediate warming of the sample happened. Subsequently, the loading device was quickly positioned in the precooled loading area of the HPF-device and sample temperature declined again (2). During inserting the loading-device into the HPF-device (3) and locking it, sample temperature again slightly increased but remained well below $0{ }^{\circ} \mathrm{C}$ as before, because HPF was quickly released within only a few seconds (4). Dashed black line: Samples were treated as before, with the difference that the precooling of the interior of the HPF-device by the precooling device (PD) has been omitted. In this way the sample temperature rapidly began to rise immediately after inserting the loading device into the HPF-device (5) and the warming rate even increased after locking the specimen pod (6). Arrows indicate the further temperature courses (not shown) that ended at $-196^{\circ} \mathrm{C}$

During HPF of the unfrozen (control) and the frozen samples, pressurization and cooling speed were in the appropriate range (see Additional file 1). Both, in controls and in extracellularly frozen samples, structural preservation of the cytoplasm, cell organelles and cell walls corresponded to the high standard known from HPF fixed tissues and cells. Cytoplasmic structure and contents of organelles appeared electron dense and there were no indications of loss in material or structural damage (Figs. 3a-d, $4 \mathrm{a}-\mathrm{f})$ as postulated in earlier investigations [20, 22, 46, 47]. Particularly in Micrasterias (Fig. 3a, b) where HPF has been employed after exposure of the cells to different unfavourable environmental conditions and cellular inhibitors
[42, 48-52], the results clearly show that the structural preservation of the extracellularly frozen cells is excellent and corresponds to that presented in the other studies. Klebsormidium crenulatum control cells (Fig. 3c, e-f) had a similar good preservation of the ultrastructure as -2 ${ }^{\circ} \mathrm{C}$ frozen samples (Fig. 3d, g). Also in Lemna (Fig. 4a, b) cytoplasmic and organelle structure are well preserved and correspond in quality to that obtained in a recent study on ionic stress effects [42]. For K. crenulatum (Fig. 3c, d) and $R$. glacialis (Fig. 4c, d) this is the first report on HPF fixed material as so far TEM-images are only available from chemically fixed samples (e.g. [53-55]). However, also in these plants all criteria demanded for excellent structure preservation seem to be fulfilled.

In the case of $P$. mugo (Fig. 4e, $\mathrm{f}$ ) the situation is different. Whereas in the other objects used for the present investigation almost all frozen samples exhibited good structure preservation, the percentage of well-preserved tissues in Pinus was low, ranging in the area of $10 \%$. This is rather due to problems with the infiltration of the needles by the resin than to insufficient fixation. In $P$. mugo particularly the duration of infiltration (see Materials and methods) as well as direction and velocity of sectioning determined the quality of the resulting sections and thus their suitability for TEM. When all criteria were met, structure preservation of both controls and extracellularly frozen $P$. mugo samples was sufficient (Fig. 4e, f). Comparison of the fixation quality with other studies is not possible, as to our knowledge all other TEM studies available on conifer needles were done by chemical fixation (see e.g. [56-59]). However, HPF fixed tissue of Pinus contorta during secondary wall formation or in the winter-dormant vascular cambium [60, 61], shows similar structure preservation as our controls and extracellularly frozen needles of $P$. mugo.

As expected, in the present study specific structural alterations could be observed in extracellularly frozen samples of all model plants which were not referable to the methodology applied but to the effects of low temperature and freezing (P. Steiner, U. Lütz-Meindl; personal communications). They mainly comprised changes in organelle structure and distribution as well as the appearance of different stages of autophagy and degeneration (Figs. 3a, b, 4b, d, f).

\section{Discussion}

The present study clearly shows that our newly developed automatic freezing unit (AFU) makes it possible to preserve frozen plant samples for electron microscopy by HPF without interrupting the cold chain. The resulting TEM images provide excellent structure preservation. The study makes clear that both, transport of the sample 
Table 1 Workflow for high pressure freezing of already frozen biological samples

\begin{tabular}{|c|c|c|}
\hline Time & Action & Effects/notes \\
\hline \multirow[t]{2}{*}{$-15 \min$} & \multirow{2}{*}{$\begin{array}{l}\text { Set air temperature inside the Plexiglas }{ }^{\circledR} \text { chamber to } 0{ }^{\circ} \mathrm{C} \\
\text { Insert a loading device and release HPF in advance }\end{array}$} & Slow precooling of the loading area \\
\hline & & Precooling of the internal components of the HPF-device \\
\hline$-5 \min$ & $\begin{array}{l}\text { Insert and lock the precooling device (PD) } \\
\text { Set air temperature inside the Plexiglas }{ }^{\circledR} \text { chamber to }-5^{\circ} \mathrm{C} \text {. The } \\
\text { following disclosures relate to the experiment on R. glacialis and } \\
\text { to the usage of the Leica Empact HPF-device (Leica Microsystems, } \\
\text { Vienna, Austria) }\end{array}$ & $\begin{array}{l}\text { Increased precooling of the loading area and of the internal compo- } \\
\text { nents of the HPF-device }\end{array}$ \\
\hline$-30 s$ & Fill $L N_{2}$ directly into the pan (up to the rim) & $\begin{array}{l}\text { Prevents the HPF-device from activating the release delay due to low } \\
\mathrm{LN}_{2} \text {-level in the pan for } 2-3 \mathrm{~min}\end{array}$ \\
\hline$-10 s$ & $\begin{array}{l}\text { Switch the fan inside the Plexiglas }{ }^{\circledR} \text { chamber permanently on and } \\
\text { remove the lid }\end{array}$ & $\begin{array}{l}\text { Develops a cold }\left(-5 \text { to }-10^{\circ} \mathrm{C}\right) \text { atmosphere around and above the } \\
\text { loading area. Important for transferring the loading device from the } \\
\text { transfer block to the loading area of the HPF-device }\end{array}$ \\
\hline $0 \mathrm{~s}$ & $\begin{array}{l}\text { Unlock and remove the PD } \\
\text { Pull out the loading device from the transfer block and quickly insert } \\
\text { it into the HPF-device } \\
\text { Promptly press 'Lock' and start HPF }\end{array}$ & $\begin{array}{l}\text { This step must be executed within max. } 8 \mathrm{~s} \\
\text { Otherwise the sample will thaw before HPF is completed }\end{array}$ \\
\hline
\end{tabular}

The following disclosures relate to the experiment on R. glacialis and to the usage of the Leica Empact HPF-device (Leica Microsystems, Vienna, Austria)

from the AFU to the HPF-device and in particular the temperature inside its sample chamber are the main critical issues. Technical adaptations were particularly necessary in these cases to avoid an interruption of the cold chain of the samples during preparation.

During freezing and sample preparation inside the AFU the temperature stability was highly satisfactory and unintentional thawing was effectively prevented. However, inserting the hands into the AFU, in spite of wearing thermal insulating gloves always remained a challenging task for the temperature control mechanisms. The consequential temperature fluctuations could finally be minimized by slow and consecutively insertion and retraction of the hands. Whereas transportation of the samples within the metallic transfer block was unproblematic, the unavoidable mechanical contact of the loading device carrying the frozen sample, with the HPF-device required numerous tricks to avoid thawing of the sample. For cryo-fixation of frozen plant tissue it would be beneficial, if the next generations of HPF-devices could optionally be equipped with extended temperature controls for precooling the loading area and the relevant internal components.
It is well known that during cryo-fixation by HPF the cooling rate declines with the distance from the inner wall of the specimen carrier [46], which in turn may reduce the depth of vitrification and promote ice crystal growth. Furthermore, high pressure does not facilitate vitrification of water and diluted solutions [35] as being present for example in cell vacuoles and intercellular spaces of distinct plant tissues. As we abstained from using any cryoprotectant or other filling medium, we originally presumed that leaf tissue of $R$. glacialis and $P$. mugo, which is rich in air filled intercellular spaces, might show insufficient preservation quality (see [62]). This is not the case. One explanation for that could be that in $P$. mugo the leaf mesophyll cells are densely arranged and have robust cell walls. Principally, but to a lesser extent, this is also true for the palisade parenchyma layer of $R$. glacialis. Furthermore, in both cases it was possible to cut out tissue pieces which perfectly fitted into the gold plated specimen carrier (see Additional file 2) which may have minimized the thermal transfer resistance between its inner wall and the specimen. This however, poses a high challenge on the person who does the preparation.

(See figure on next page.)

Fig. 3 TEM micrographs of the alga Micrasterias denticulata $(\mathbf{a}, \mathbf{b})$ and the alga Klebsormidium crenulatum $(\mathbf{c}-\mathbf{g})$ after freezing $(\mathbf{b}, \mathbf{d}, \mathbf{g})$ in comparison to $20^{\circ} \mathrm{C}$ controls $(\mathbf{a}, \mathbf{c}, \mathbf{e}, \mathbf{f}) \cdot \mathbf{a} 20^{\circ} \mathrm{C}$ control of Micrasterias shows single mitochondria (m), mucilage vesicles (mv), a part of the chloroplast (chl) and a part of the vacuole (v). $\mathbf{b}$ Micrasterias cell after $-2^{\circ} \mathrm{C}$ freezing with aggregated and fused mitochondria (m), endoplasmic reticulum (er), dictyosome (d), mucilage vesicles (mv) and chloroplast (chl). c $20^{\circ} \mathrm{C}$ control of Klebsormidium shows vacuole (v) and cytoplasm (cyt) with single mitochondrion $(\mathrm{m})$, chloroplast (chl), dictyosome (d), multi vesicular body (mvb), peroxisome (p) and nucleus (n). d Klebsormidium after $-2^{\circ} \mathrm{C}$ freezing shows chloroplast (chl), nucleus (n), peroxisome (p), vacuole (v) and cell wall (cw). e High magnification of $20^{\circ} \mathrm{C}$ control of Klebsormidium shows double membranes (arrows) and cristae (asterisks) of mitochondrion (m) and chloroplast (chl). $\mathbf{f}$ High magnification of $20^{\circ} \mathrm{C}$ control of Klebsormidium with chloroplast (chl) and cytoplasm (cyt), surrounded by the plasma membrane with the typical two-leaflet structure (arrows) and cell wall (cw). $\mathbf{g}$ High magnification of Klebsormidium frozen at $-2{ }^{\circ} \mathrm{C}$ shows peroxisome (p), vacuole (v), cell wall (cw) and double membranes (arrows) of chloroplast (chl) and nucleus (n) 

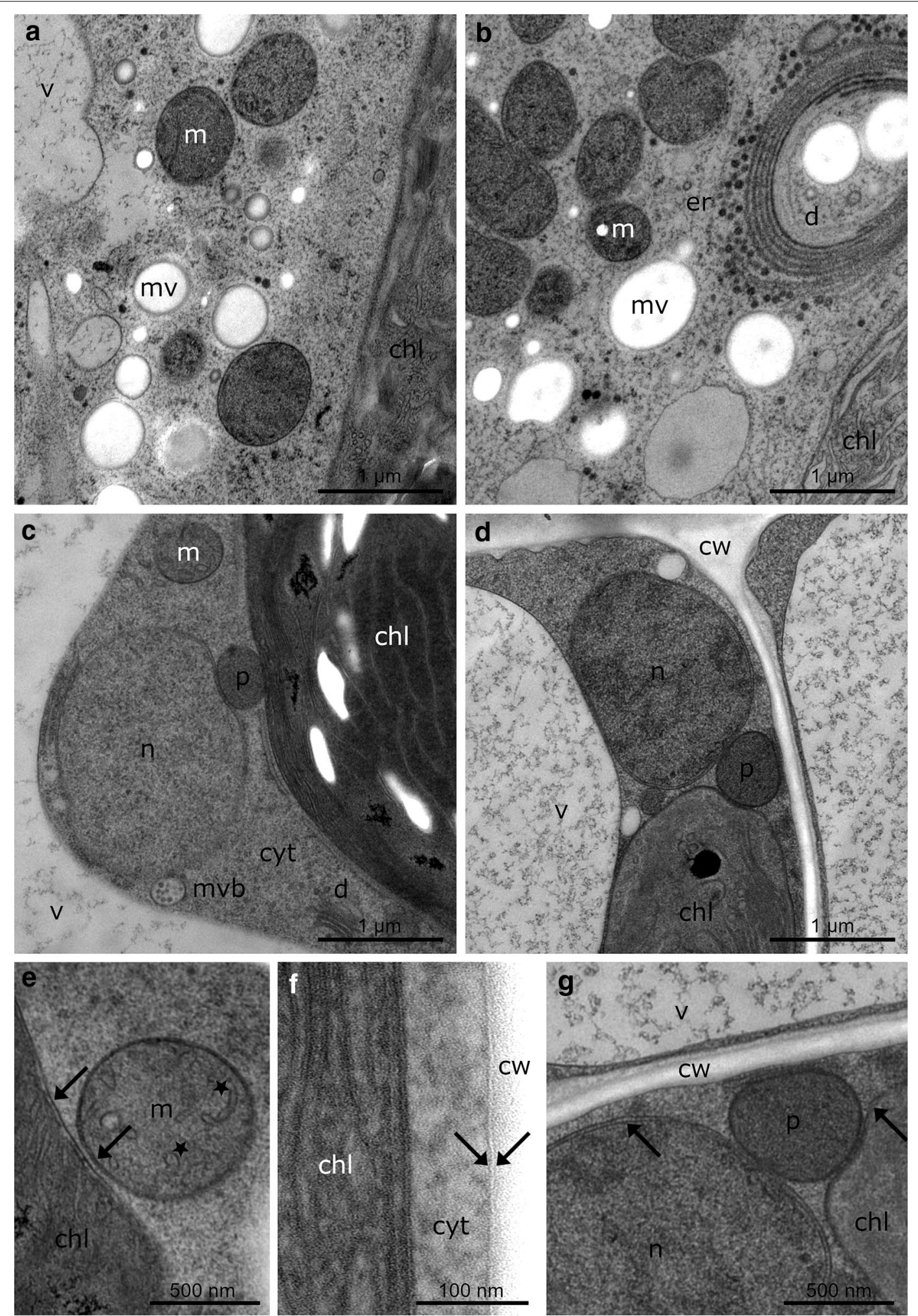

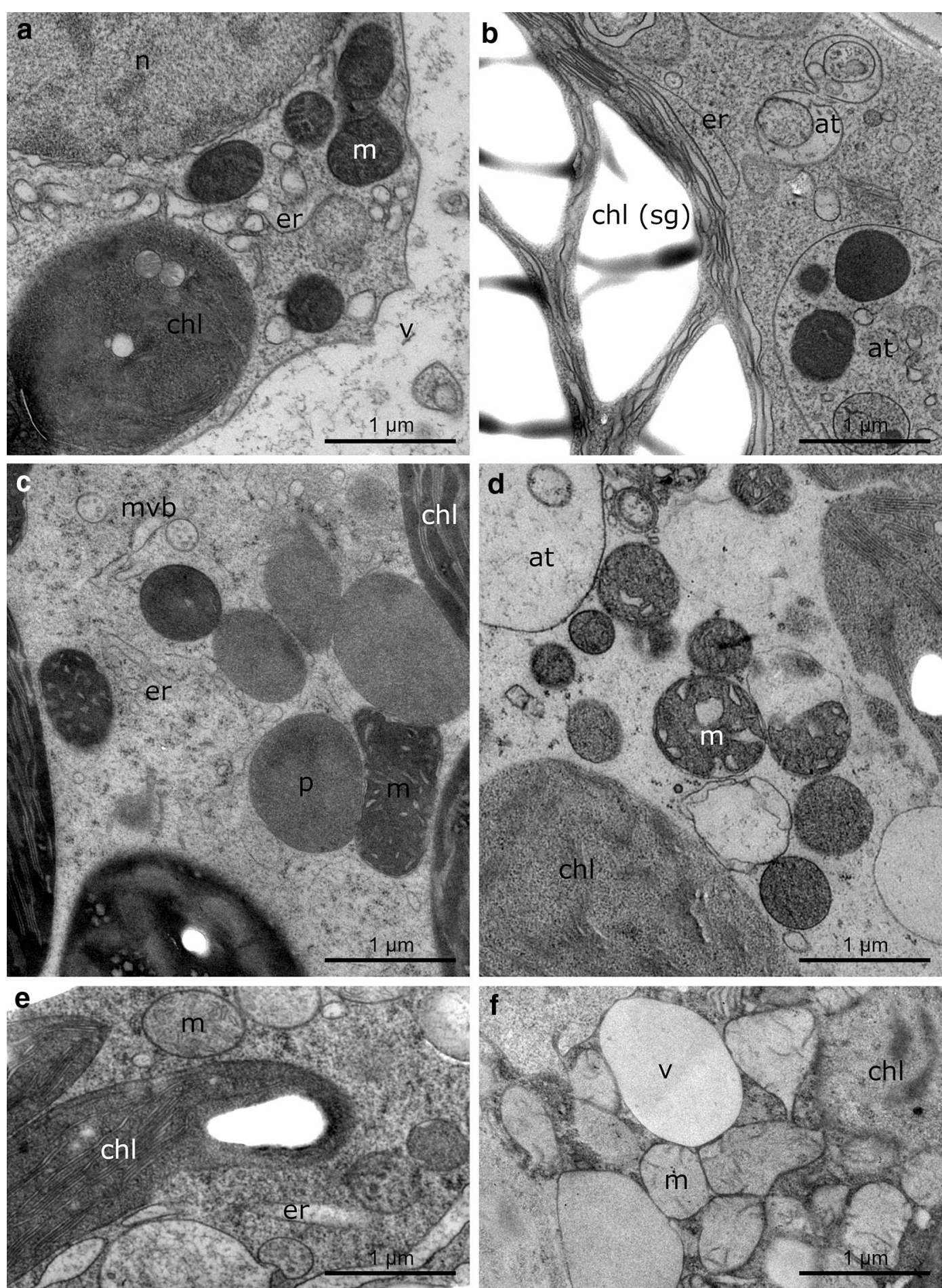

Fig. 4 TEM micrographs of the higher freshwater plant Lemna sp. (a, b), the higher alpine plant Ranunculus glacialis (c, d) and the higher alpine plant Pinus mugo (e-f) after freezing $(\mathbf{b}, \mathbf{d}, \mathbf{f})$ in comparison to temperate controls $(\mathbf{a}, \mathbf{c}, \mathbf{e})$. a $20^{\circ} \mathrm{C}$ control of Lemna shows vacuole (v), mitochondria (m), chloroplast (chl), endoplasmic reticulum (er) and nucleus (n). $\mathbf{b}$ Lemna leaf after $-2^{\circ} \mathrm{C}$ freezing shows chloroplast (chl) with enlarged starch grains (sg), endoplasmic reticulum (er) and signs of degradation and autophagic structures (at). $\mathbf{c} 4^{\circ} \mathrm{C}$ control of Ranunculus shows mitochondria $(\mathrm{m})$, peroxisome (p), multivesicular bodies (mvb), endoplasmic reticulum (er) and a part of the chloroplast (chl). $\mathbf{d}$ Ranunculus leaf after $-5^{\circ} \mathrm{C}$ freezing with aggregated mitochondria $(\mathrm{m})$ and signs of degradation and autophagic structures (at). e $20^{\circ} \mathrm{C}$ control of Pinus shows mitochondria (m), chloroplast (chl) and endoplasmic reticulum (er). f Pinus needle after $-6^{\circ} \mathrm{C}$ freezing shows chloroplast (chl), mitochondria (m) and vacuole (v) 
In case of $M$. denticulata and $K$. crenulatum the addition of a cryoprotectant was not necessary, because of the absence of air filled spaces around algae. This has been proven in numerous earlier studies. In summary, cryofixation of the frozen samples in case of Micrasterias, Klebsormidium, Ranunculus and Lemna was as successful as the fixation of the unfrozen controls. In this context attention shall be paid to the study of Yakovlev and Downing [63] who suggested that, during HPF, ice formation in the surrounding medium can enhance the cooling rate and therefore improve cryo-preservation. The more than threefold heat conductivity of ice compared to liquid water may thus have contributed to the good preservation of the structural integrity of the already (extracellularly) frozen samples.

Despite the well preserved cellular ultrastructure of the frozen samples, some questions concerning the fate of the hexagonal ice (Ice Ih), as being present in the frozen specimen before HPF takes place, remain open. The phase diagram of water is complex [64] and does not take into account dynamics like rapid changes of pressure and temperature. Therefore, a precise prediction on what will happen with Ice Ih during HPF cannot be given. It is known that water can supercool to $-92{ }^{\circ} \mathrm{C}$ at a pressure of $205 \mathrm{MPa}$ and its melting point is decreased to $-22{ }^{\circ} \mathrm{C}[46,65,66]$. And it is not fully clear whether the rapid pressurization during HPF induces amorphization of Ice Ih in a comparable way as described at $77 \mathrm{~K}$ and $1000 \mathrm{MPa}$ by Mishima et al. [66]. At last it can't be ruled out that ice in the frozen specimen became liquid during pressurization [67] for some milliseconds until final vitrification. As on the cellular level related responses can occur within very short time-spans [46], this option must not be completely discarded when evaluating the results.

On the other hand Bauer et al. [68] reported a density driven phase transition of Ice Ih to Ice II and Ice III at relatively high temperatures $(170-230 \mathrm{~K})$ when high pressurization rates up to $4000 \mathrm{MPa}^{\prime} \mathrm{min}^{-1}$ were applied, which are lower than that observed during HPF (Additional file 1. $1:>10^{6} \mathrm{MPa}^{\circ} \mathrm{min}^{-1}$ ). They clearly proved a crucial impact of pressurization rate on the fate of normal hexagonal ice. Thus, during HPF a direct transition of already present Ice Ih to other ice forms or to a glassy state without intermediate melting appears possible.

Nevertheless, due to the lack of experimental studies concerning the behaviour of hexagonal ice during HPF conditions, presently this topic cannot be fully answered.

\section{Conclusions}

We presented a method for adapting a commercial HPFdevice for cryo-fixation of already frozen plant samples without intermediate thawing. The unicellular alga $M$. denticulata, the filamentous algae $K$. crenulatum and leaf tissues of the higher plants Lemna sp., R. glacialis and $P$. mugo were frozen by a software controlled, newly developed automatic freezing unit (AFU). The subsequent preparation for TEM took place within the AFU at different freezing temperatures and the following cryo-fixation by HPF was performed without intermediate thawing. The resulting electron micrographs show excellent preservation of all ultrastructural details and corresponded to those of unfrozen controls after cryo-fixation. The presented method is currently applicable to temperatures down to $-35^{\circ} \mathrm{C}$ and has high potential for further studies on freezing effects on plants at an ultrastructural level. It may thus help to increase our knowledge on the different mechanisms causing freeze damage on a cellular level. Our results suggest that the method is also applicable to bacteria, fungi and animal tissue. Its use in combination with electron tomography (ET), focused ion beam-scanning electron microscopy (FIB-SEM) and analytical TEM such as energy-dispersive X-ray spectroscopy (EDX) and electron energy loss spectroscopy (EELS) may yield new insights into possible chemical changes of e.g. cell walls, metabolites or storage products during freezing.

\section{Methods \\ Plant material}

In order to demonstrate successful HPF of already frozen plant material we used five plant species on different evolutionary levels that inhabit contrasting ecosystems and are adapted to freezing temperatures to different degrees:

\section{Micrasterias denticulata (Bréb.)}

Micrasterias denticulata, an unicellular freshwater greenalga, inhabiting acid peat bogs up to an altitude of about $3000 \mathrm{~m}$ a.s.l. [69] has become a well-studied model organism in terms of cytomorphogenesis, cell physiology and stress response as well as ultrastructural research (for review see $[37,70,71])$. M. denticulata cells are large (200 $\mu \mathrm{m}$ in diameter) and reveal a highly ornamented, symmetric cell pattern that is manifested in two semicells and allows recognition of any environmental impact easily. Each semi-cell contains one large chloroplast and two large vacuoles. The cells were cultivated in a low concentrated liquid desmid nutrient solution [72] at $+20{ }^{\circ} \mathrm{C}$ and $100-150 \mu \mathrm{mol}$ photons $\mathrm{m}^{-2} \cdot \mathrm{s}^{-1}$ (time ratio day/night: $14 / 10 \mathrm{~h}$ ).

\section{Klebsormidium crenulatum (Kütz.) Lokhorst}

Klebsormidium crenulatum (SAG 2415, Culture Collection of Algae, Göttingen, Germany) is an aeroterrestrial and desiccation tolerant, filamentous greenalga species which occurs in different terrestrial habitats (e.g. soil crusts). Samples were previously isolated from soil 
Fig. 5 Automatic freezing unit (AFU) for controlled freezing and preparation of biological samples at freezing temperatures. a Top view. b Front view. The original lid of the laboratory freezer (1) was replaced by a top unit made out of thermally insulating material (2) which was covered by a detachable transparent Plexiglas ${ }^{\circledR}$ pane (3). The top unit had two holes (4) through which thermally insulated gloves (5) for manipulation purposes were inserted. Temperature control was realized by two software controlled heating elements (6) which were equipped with miniature fans. Additionally, at the bottom of the freezer an array of four powerful fans (7) was placed to ensure good ventilation and temperature homogeneity within the freezer. A wire mesh (8) prevented the unintentional drop down of tools from the working (9) and the storage shelf (10). For freezing algal suspensions the working shelf was equipped with a fan (11) which blew air directly to the underside of the object carrier (12) to which three glass dishes with each three indentations (13) were placed. The central indentation, into which the control temperature sensor was plunged, was filled with $\mathrm{NaCl}$-solution (black). For freezing of leaves a different working shelf without object carrier was used (not shown). Arrows indicate the main directions of the internal airflows

particles (Schönwieskopf near Obergurgl, Tyrol, $2.350 \mathrm{~m}$ a.s.l., $49^{\circ} 50^{\prime} 59.88^{\prime \prime} \mathrm{N}, 11^{\circ} 0^{\prime} 54.18^{\prime \prime} \mathrm{E}$ ) and cultivated in modified Bold's basal medium [73] at $+20^{\circ} \mathrm{C}$ and a photosynthetic flux density (PPFD) $30 \mu \mathrm{mol}$ photons $\mathrm{m}^{-2} \cdot \mathrm{s}^{-1}$ (time ratio day/night: 16/8 h) until the experiments started.

\section{Lemna sp.}

Lemna is a widespread genus of free-floating aquatic freshwater plants and is frequently used for toxicological studies (e.g. [40, 42, 74]). Lemna was cultivated in Hoagland's medium [75] at $+20{ }^{\circ} \mathrm{C}$ and PPFD 100-150 $\mu$ mol photons $\mathrm{m}^{-2} \cdot \mathrm{s}^{-1}$ (time ratio day/night: 12/12 h) until the experiments started. Leaves of Lemna were prepared for TEM.

\section{Ranunculus glacialis $L$}

$R$. glacialis is one of the highest ascending flowering plants (up to $4250 \mathrm{~m}$ a.s.l.) [76], and is well-studied in terms of its anatomy [53] and eco-physiology [44, 77-79]. It can be found in the upper alpine and nival zones of the European Alps but also in arctic and subarctic regions, where its fleshy and slightly succulent leaves are exposed to the risk of sporadic freezing during the entire vegetation period.

During summer whole individuals of $R$. glacialis were carefully excavated together with roots and surrounding soil from the summit area of the "Kleiner Isidor" (Stubaier Alps, Tyrol, $3150 \mathrm{~m}$ a.s.l., $46^{\circ} 58^{\prime} 24.71^{\prime \prime} \mathrm{N}, 11^{\circ} 06^{\prime}$ $27.88^{\prime \prime}$ E). After transportation within a cooling box, the plants were put into a climate chamber and held at $+4{ }^{\circ} \mathrm{C}$ and a PPFD $80 \mu \mathrm{mol}$ photons $\mathrm{m}^{-2} \cdot \mathrm{s}^{-1}$ (time ratio day/ night: $14 / 10 \mathrm{~h}$ ) for 2 days until the experiments started.

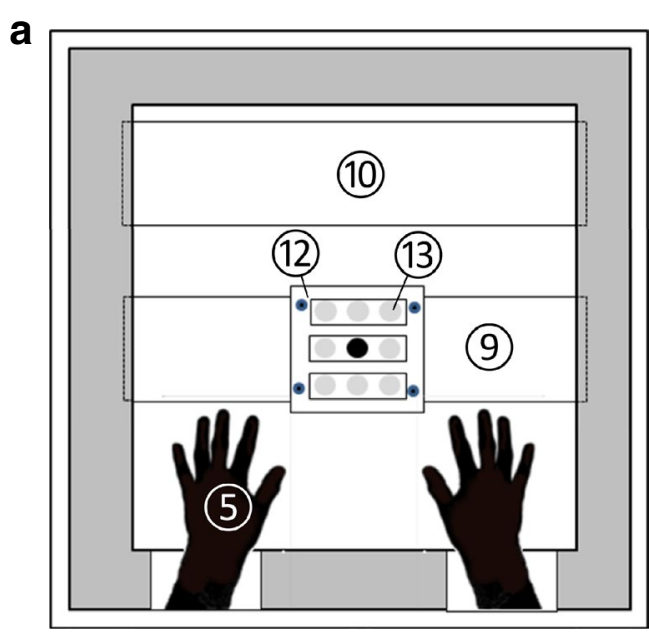

b

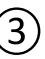

(2)

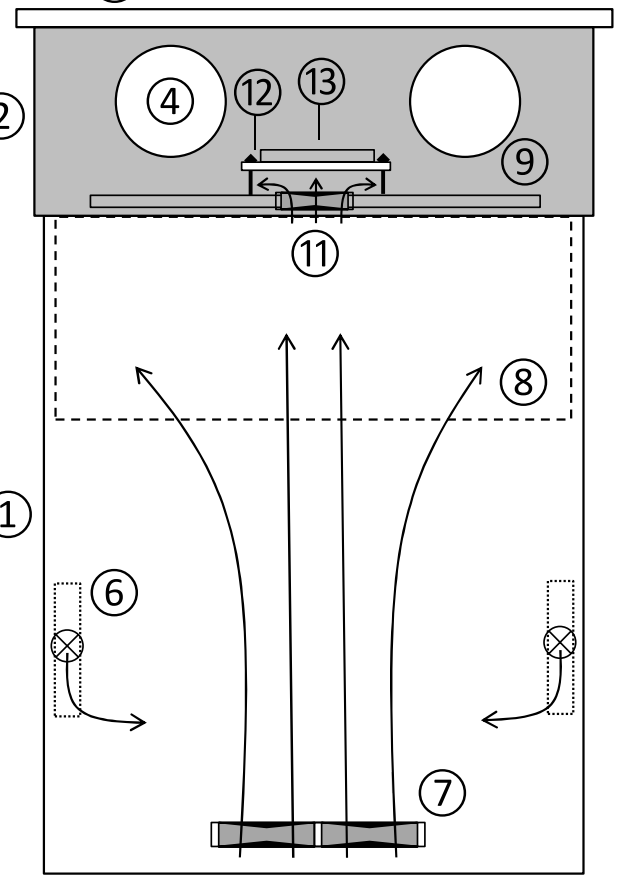

\section{Pinus mugo Turra ssp. mugo}

Pinus mugo is a typical representative of the subalpine knee timber zone. It has a shrubby-like growth-habit and reaches a maximum height of ca. $3 \mathrm{~m}$. During late winter, twigs $(30-40 \mathrm{~cm})$ were collected at Mt. Patscherkofel (Innsbruck, $1940 \mathrm{~m}$ a.s.l., $47^{\circ} 12^{\prime} 38.4^{\prime \prime} \mathrm{N} / 11^{\circ} 27^{\prime} 5.98^{\prime \prime}$ E), and transported to the laboratory within a snowfilled cooling box. Twigs were cut back under water and put into small plastic vials which were filled with tap water. Then each 3 of them were placed into 2 automatic 
freezing units (AFU) (see next chapter) which were precooled to $+4{ }^{\circ} \mathrm{C}$ until controlled freezing to target temperature was started.

\section{Sample exposure to freezing temperatures}

For controlled freezing of plants we developed an automatic freezing unit (AFU) from a common laboratory freezer (PLTA 0986, National Lab, Mölln, Germany; Fig. 5) which we equipped with two ventilated (HA40201V4-999, SUNON, Kaohsiung, Taiwan) heating elements (Nimbus B, 12 V/100 W, DBK David and Baader, Rülzheim, Germany). They were connected to a supply unit consisting of power supplies, commercial relays, modules for communications, control and temperature measurements (cRIO 9073: $266 \mathrm{MHz}$ real time controller, NI 9264: 16 bit analog output modules, NI 9213: 16 channel thermocouple modules; all from National Instruments, Austin, TX, USA) and other necessary electronics. The temperature inside the freezer was continuously controlled and recorded by T-control software (Additional file 3), which we developed on a LabView platform (LabView 2012, National Instruments, Austin, TX, USA). Based on different algorithms the software allowed to precisely control (typically $< \pm 0.2{ }^{\circ} \mathrm{C}$ or lower) the temperatures inside the AFU by switching on/ off the heating elements following the pattern of a PWM (pulse with modulation). In this way user defined temperature courses in terms of cooling and warming rates with a minimum target temperature $-35^{\circ} \mathrm{C}$ at an ambient temperature $+25^{\circ} \mathrm{C}$ could be realized. Furthermore, up to 32 fine wire thermocouple sensors (Type $\mathrm{T}$, solder junction diameter $<0.2 \mathrm{~mm}$, TT-Ti-40, Omega Engineering Inc., Stamford, USA) were connected to simultaneously record further relevant temperatures (e.g. leaf and alga suspension temperatures) by the system. For preparation of the samples at the selected freezing temperature, the AFU was permanently equipped with a highly thermal insulating (Styrodur ${ }^{\circledR}$, BASF, Ludwigshafen, Germany) top unit covered by a detachable pane of transparent Plexiglas ${ }^{\circledR}$ (20 mm, XT 29010, Röhm, Darmstadt, Germany) to optionally enable controlled illumination of the samples during freezing. The panelled side walls of the top unit had two adjacent horizontal holes (diameter: $120 \mathrm{~mm}$ ). In these holes thermally insulating gloves (Thermo, HM Müllner, Eugendorf, Austria) were mounted. This allowed the preparation of frozen samples with minimized heat input into the freezing compartment and hence prevented undesired increases of the sample temperature. Inside the top unit a small bench and a storage shelf, both made of Plexiglas ${ }^{\circledR}$, were located for preparation purposes and for keeping the preparation tools at a similar temperature as the samples.
In case of $\boldsymbol{M}$. denticulata and $\boldsymbol{K}$. crenulatum an additional pane (Plexiglas ${ }^{\circledR}$ ) was mounted to the bench. On this pane, three small glass dishes $(80 \times 26 \times 8 \mathrm{~mm})$ with three pits each (diameter: $20 \mathrm{~mm}$ ), for placing the algae, were positioned (Fig. 5). The central pit was filled with $\mathrm{NaCl}$-solution. A fine-wire thermocouple sensor (see before) was plunged into it. This reference sensor was needed for control purposes only. It continuously measured the actual temperature of the $\mathrm{NaCl}$-solution which was shown by preceding tests to be almost similar $\left( \pm 0.2{ }^{\circ} \mathrm{C}\right)$ to the temperature of the adjacent alga suspensions. The $\mathrm{NaCl}$-solution was required for surrounding the sensor by a liquid with a similar heat storage capacity, compared to the alga suspensions. This also prevents freezing, as the occurrence of a massive freezing exotherm at temperatures $<0{ }^{\circ} \mathrm{C}$ would have made it impossible to further control the suspension temperatures. Direct temperature measurement of the individual suspensions was not possible because the thermocouple sensors were shown to promote undesired ice nucleation and would have thus induced early and unpredictable freezing of the alga suspensions. The time of freezing and the desired ice formation temperature had to be controlled in any case (see next chapter).

We filled $1.5 \mathrm{ml}$ of cell suspension (algae within their nutrient medium) into each (in total 8) indentation of the precooled $\left(+4{ }^{\circ} \mathrm{C}\right)$ glass dishes and-after a stabilisation phase (e.g. $30 \mathrm{~min}$ )-cooled the samples down to target temperatures (M. denticulata and $K$. crenulatum: $-2{ }^{\circ} \mathrm{C}$ ) which-as verified by preceding tests-were expected not to cause lethal damage to the cells. The cooling rate applied $\left(-2{ }^{\circ} \mathrm{C}^{-1}{ }^{-1}\right.$; Fig. 1$)$ is comparable with that used in other studies on algae $\left(-4{ }^{\circ} \mathrm{C}^{\prime} \mathrm{h}^{-1}\right.$ : [80], $-2.4{ }^{\circ} \mathrm{C}^{\circ} \mathrm{h}^{-1}$ : [81]. When the target temperature was attained, preparation of the still unfrozen (supercooled) samples for HPF was started.

Whole individuals of Lemna sp. were put into small Eppendorf tubes which were filled with tap water. Temperature treatment started at $+4{ }^{\circ} \mathrm{C}$ and ended at $-2{ }^{\circ} \mathrm{C}$ $\left(-2{ }^{\circ} \mathrm{C}^{\circ} \mathrm{h}^{-1}\right)$. Freezing was induced by dipping the tip of a cold dissection needle into the water to induce ice nucleation and freezing of the leaves.

For freezing of $\boldsymbol{R}$. glacialis we placed the petioles of the leaves into small cups filled with tap water and a small amount of solution containing ice nucleating active (INA) bacteria (Pseudomonas syringae). This was done to prevent extended supercooling and to induce ice nucleation [82], and subsequently, freezing of the leaves within a temperature range corresponding well to the situation at the natural growing site $\left(-2{ }^{\circ} \mathrm{C}\right.$ to $-3{ }^{\circ} \mathrm{C}$; Stegner, Schäfernolte and Neuner, personal communication). Thermocouple sensors (see before) were mounted to the leaves by air permeable 
a

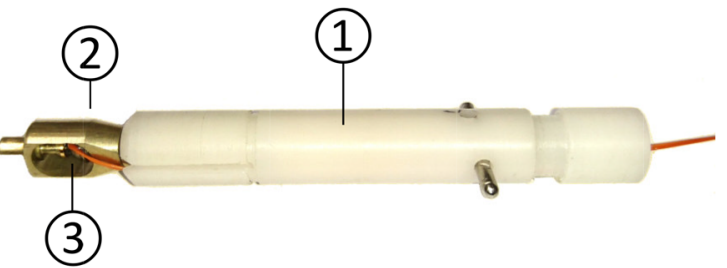

C

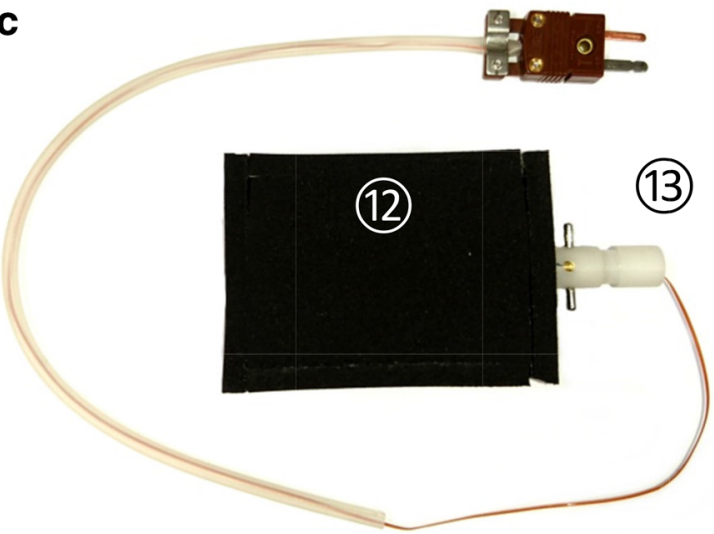

b

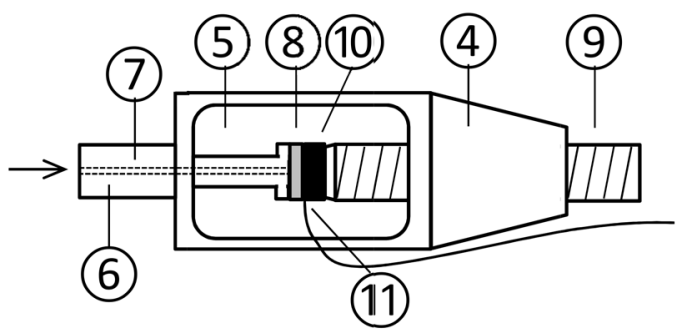

d

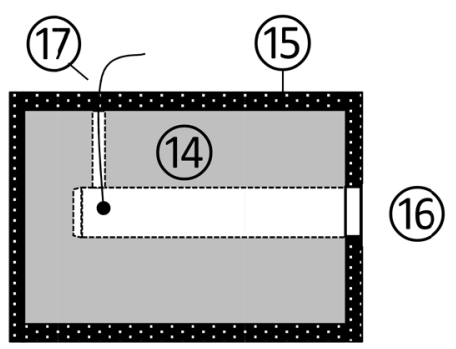

Fig. 6 Adapter for measuring sample temperature during transfer within the transfer block and high pressure freezing. a Temperature measurement adapter (TMA) made from a standard loading device (1) consisting of a plastic tube with internal mechanical components and the specimen pod (2) with connected thermocouple sensor (3). b Specimen pod (schematic drawing, not to scale) (4) with two windows (5) through which jet streams of $\mathrm{LN}_{2}$ are applied and the pressure adapter (6) with an internal copper tube (7) for building up high hydraulic pressure (arrow) by methyl cyclohexane (liquid) which is directly forwarded to the bottom of the flat specimen carrier (8) which contains the sample. A grub screw (9) with an industrial diamond (10) on its tip seals the open side of the flat specimen carrier and ensures sufficient mechanical stability of the set-up. A thermocouple sensor (11) was connected to the flat specimen carrier to monitor sample temperature during transfer and high pressure freezing. $\mathbf{c}$ Transfer block (12) with affixed envelope of sponge rubber and inserted TMA (13). d Drawing (section) of the transfer block, showing the aluminium body (14), the sponge rubber envelope (15), the drill holes into which the loading device (16) and the thermocouple sensor for monitoring sample temperature during transportation (17) are inserted

adhesive tape (Transpore ${ }^{\mathrm{TM}}, 3 \mathrm{M}$, Österreich, Perchtoldsdorf, Austria). Then the samples were covered by a hemispherical glass bowl to reduce air movements and to promote the detection of freezing exotherms, indicating that extracellularly freezing of the leaves has taken place.

The minimum freezing temperature (target temperature) was specified based on the results of preceding tests for determining the actual freezing resistance of the sampled leaves following the protocol as described by Neuner and Buchner [45]. In vivo chlorophyll measurements $\left(\mathrm{F}_{\mathrm{v}} / \mathrm{F}_{\mathrm{m}}\right)$ showed that the temperature threshold $\left(\mathrm{LT}_{\mathrm{i}}\right)$ at which initial freezing damage occurred, was at $-7{ }^{\circ} \mathrm{C}$. We were aware that this kind of viability assessment would only provide information on the functionality of photosystem II (PS II). Temporary and reversible damage or impairment of cells or sub-cellular structures cannot be captured by this assay.
Thus, we exposed the samples to a temperature range starting at $+4{ }^{\circ} \mathrm{C}$ and ending at a target temperature of $-5{ }^{\circ} \mathrm{C}$, which was higher by $+2{ }^{\circ} \mathrm{C}$ than $\mathrm{LTi}$, at which initial freezing damage to PS II was expectable. The cooling rate applied $\left(-3{ }^{\circ} \mathrm{C}^{\mathrm{r}} \mathrm{h}^{-1}\right)$ (Fig. 1) is commonly used in stress physiological research on higher plants and close to that observed in nature $[8,82]$. When the target temperature was attained, preparation of the already frozen leaf samples was started. Freezing of $\boldsymbol{P}$. mugo in principle followed a similar procedure. The pre-determined $\mathrm{LT}_{\mathrm{i}}$ was $<-20{ }^{\circ} \mathrm{C}$, and so we applied the following temperature course: Start temperature: $+1{ }^{\circ} \mathrm{C}$, target temperature: $-6{ }^{\circ} \mathrm{C}$, cooling rate: $-3{ }^{\circ} \mathrm{C}^{\cdot} \mathrm{h}^{-1}$.

\section{Sample preparation for high-pressure-freezing (HPF)}

The preparation of the samples took place within the AFU. In case of $M$. denticulata and $K$. crenulatum 

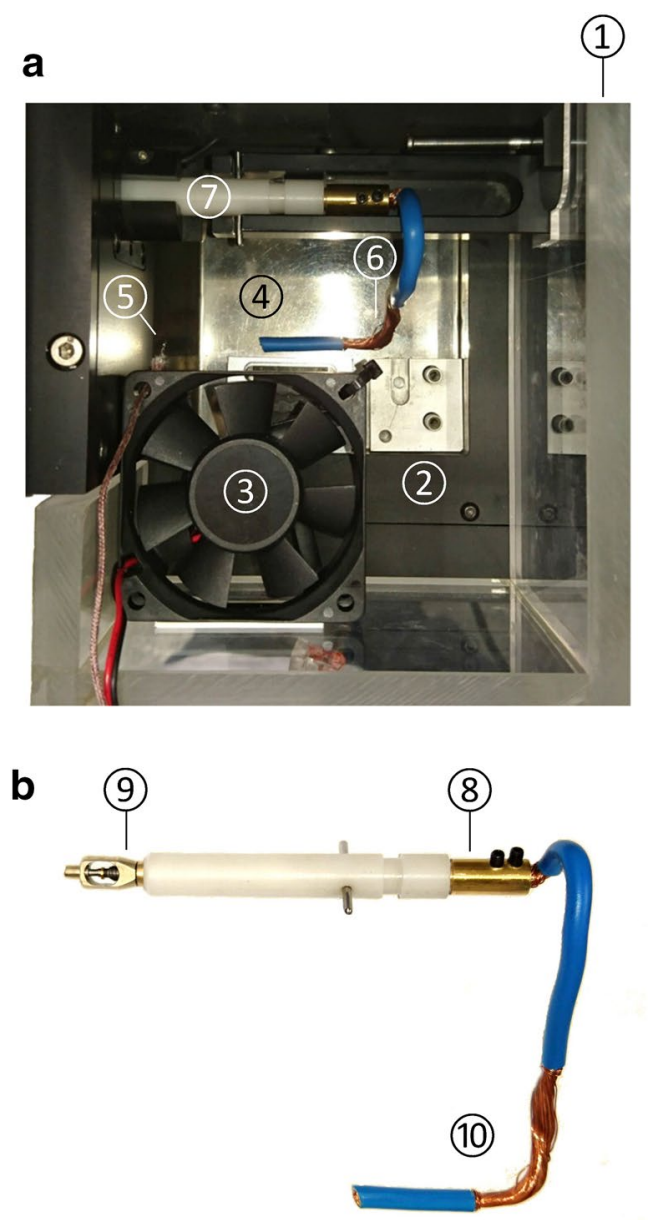

Fig. 7 Components for cooling the HPF-device. a Cooling chamber for cooling the loading area of the HPF-device (top view, lid removed). Walls out of Plexiglas ${ }^{\circledR}(1)$ enclose the entire loading area (2), while a fan (3) is generating airflow to the pan (4) which in normal operation is filled with $\mathrm{LN}_{2}$. As a consequence evaporation of $\mathrm{LN}_{2}$ will be increased and the loading area will rapidly be filled with cold, gaseous $\mathrm{N}_{2}$ which, on the other hand, cools all components and metal surfaces of the loading area, and prevents introduction of water vapour from the ambient atmosphere. For automatic temperature control a thermocouple sensor (5) is installed. The copper strains (6) of the inserted precooling device (PD) (7) lead to the pan and are surrounded by $\mathrm{LN}_{2}$. $\mathbf{b}$ PD made from a standard loading device. The internals were removed and replaced by an alloy rod (8) to which a standard specimen pod (9) and a copper strain (10) were screwed

several cells or alga filaments, respectively, were collected from the still supercooled cell suspension and placed into a gold plated flat specimen carrier (interior dimensions: $1200 \times 200 \mu \mathrm{m}$, item Nr. 16706897, Leica Microsystems, Vienna, Austria) of the high pressure freezer together with the surrounding nutrient solution. For transferring as many single cells of $M$. denticulata as possible, cells were wrapped in cotton fibres [47]. Ice nucleation was induced by carefully dipping the tip of a dissection needle into the alga suspension, thereby carrying over a tiny portion of ice crystals originating from the inner wall of the freezer. This did not lead to freezing of the algae cells themselves but only to freezing of the surrounding aqueous medium. The further preparation in principle followed the instructions of the manufacturer as described by Studer [83]. First, the flat specimen carrier with the frozen alga suspension was mounted to the specimen pod. Then the specimen pod was screwed to the loading device which was intermediately inserted into the hole of a precooled aluminium transfer block (Fig. 6) to keep the sample at the chosen freezing temperature during the impending transfer to the HPF-device (Leica Empact, Leica Microsystems, Vienna, Austria). The entire preparation procedure was conducted at $-2{ }^{\circ} \mathrm{C}$, and was facilitated by a self-adapted binocular microscope (Stereo Star Zoom, Reichert, Vienna, Austria) which was placed on the transparent Plexiglas ${ }^{\circledR}$ lid.

In case of Lemna sp., R. glacialis and P. mugo the procedure was similar. Small discs (diameter: $1 \mathrm{~mm}$ ) of the leaves were punched out from the frozen leaf blade (Lemna sp., $R$. glacialis) by a special punching tool (item Nr. 706892, Leica Microsystems, Vienna, Austria). Then the frozen leaf discs were transferred into the gold plated flat specimen carriers (interior dimensions $1200 \times 200 \mu \mathrm{m}$ or $1200 \times 400 \mu \mathrm{m}$, item Nr. 16706899, Leica Microsystems, Vienna, Austria) and processed in a similar manner as described for Micrasterias (see above). In case of $P$. mugo thin cross sections from the needles (ca. $3 \mathrm{~cm}$ from the tip) were cut using a standard razor blade, and each two of them were placed facing each other into a gold plated flat specimen carrier (interior dimensions $1200 \times 400 \mu \mathrm{m}$, see above).

In all cases we did not add cryoprotectants such as sucrose and glycerol, because they are osmotically active and would have led to cell dehydration and undesirable consequences on the cellular ultrastructure [35, 46]. Recently, it was demonstrated by Yakovlev and Downing [63] that minimizing the amount of cryoprotectants may potentially improve preservation of cellular ultrastructure. Also the addition of the frequently used 1-hexadecene [84] was not performed because of its toxic effects on growing Micrasterias cells and the subsequent ultrastructural changes [47].

\section{High pressure freezing of the frozen samples}

As it is not possible to directly measure and control the sample temperature during transfer from the AFU to the HPF-device and during the following process of high pressure freezing, the HPF-device had to be equipped with additional components. Extensive preceding tests 
were performed to develop a precisely defined workflow which ensures that thawing of the samples can be excluded.

\section{Temperature measuring adapter for directly measuring sample temperature}

As the cooling rate sensor of the HPF-device does not reliably reflect the actual sample temperature, we adapted a loading device for continuously measuring sample temperature directly at the flat specimen carrier. For that, we threaded a fine wire thermocouple sensor (see before) through the interior of the loading device and sandwiched the sensor tip to the flat specimen carrier. The resulting temperature measuring adapter (TMA, Fig. 6a, b) allowed us to monitor the sample temperature with high temporal resolution (250 ms), not only during the transfer from the AFU to the HPF-device but also during the whole HPF. This was necessary for developing the workflow (see below) which reliably ensures preservation of the sample temperature within a narrow range, even if it is not monitored.

\section{Device for transferring the frozen samples at ambient temperature}

Tests with the TMA showed that frozen samples $\left(-4{ }^{\circ} \mathrm{C}\right)$ mounted on a loading device thaw within $<3 \mathrm{~s}$, when being exposed to ambient temperature (ca. $+25{ }^{\circ} \mathrm{C}$ ). Therefore, to avoid thawing of the sample during transportation, we used an aluminium block $(60 \times 40 \times 30 \mathrm{~mm})$ which had a suitable drill hole $(10 \mathrm{~mm})$ into which a loading device could be inserted. Through a second drill hole (diameter $0.8 \mathrm{~mm}$ ) a thermocouple sensor (see above) was inserted to measure internal air temperature of the $10 \mathrm{~mm}$ drill hole. The resulting transfer block was surrounded by selfadhesive sponge rubber (Fig. 6c, d) and located inside the AFU during freezing and preparation, so that its temperature was kept similar to the sample temperature. When preparation within the AFU was finished, the loading device was inserted into the transfer block and quickly moved to the HPF-device for further processing.

\section{Cooling the loading area of the HPF-device}

Both static and moving parts of the whole loading area of the HPF-device needed to be precooled below the freezing point before a frozen sample on the loading device could be placed on the slider for insertion into the HPF-device. For this, a chamber $(150 \times 120 \times 80 \mathrm{~mm})$ of Plexiglas ${ }^{\circledR}(10 \mathrm{~mm})$ with a removable lid was built that enclosed the whole loading area of the HPF-device. The chamber was equipped with a thermocouple sensor (see above) and a small axial fan (KD1206PHS2, Sunon,
Kaohsiung, Taiwan) which blew air vertically downwards to the pan filled with $\mathrm{LN}_{2}$ (Fig. 7a).

To control the air temperature inside the chamber, we used a simple on/off control provided by the T-control software: The fan was automatically turned on when the desired target temperature was exceeded. During operation, the fan rapidly increased the rate of evaporation of the LN2, creating a dense mist of cold, gaseous $\mathrm{N}_{2}$, that cooled all metal surfaces of the loading area until the temperature dropped below the desired temperature. Then the fan was automatically switched off until the desired target temperature was exceeded again.

Additionally, when removing the lid and keeping the fan operating continuously, also air temperature in close spatial vicinity to the opened chamber could be held well below the freezing point. In this way, the short-term transfer of the loading device from the transfer block into the precooled loading area of the HPF-device became possible without thawing of the sample.

\section{Device for precooling the interior of the HPF-device}

The last and most difficult step in realizing a continuous cold chain from sample preparation to HPF was cooling the internal components of the HPF-device which get in direct mechanical contact with the specimen pod after inserting and locking the loading device. The temperature of the components of the locking mechanism is normally between $+20{ }^{\circ} \mathrm{C}$ and $+30{ }^{\circ} \mathrm{C}$ due to the heat development inside the HPF-device by electronics and by special heating elements. To remove this heat and to effectively cool the related internal components without modifying the HPF-device, we designed a special precooling device (PD) which we inserted into the HPF-device 5 min before cryofixation started. The PD was built by modifying a normal loading device and replacing the internal components by a massive rod of alloy. To the tip of this rod a standard specimen pod was screwed in order to allow locking the PD, so that the locking mechanism could get into mechanical contact with it. The rear side of the alloy rod was made hollow, so that a copper strand $\left(6 \mathrm{~mm}^{2}\right)$ could be inserted and fixed by two transversal mounted screws (Fig. 7b). The other end of the copper strand was submersed in $\mathrm{LN}_{2}$. In this way, inserting and locking the $\mathrm{PD}$ resulted in a significant reduction of the internal temperature of the HPF-device and its locking mechanism. If subsequently the PD was quickly replaced by a loading device with a frozen sample, HPF of the sample was possible entirely at the required freezing target temperatures.

\section{Workflow for HPF of frozen samples}

Based on numerous preceding experiments using the TMA and PD a special workflow was established (Table 1). This workflow and in particular the related 
time frames therein must be strictly met to ensure that at any time intolerable temperature increase or even intermediate thawing of the sample will not occur.

\section{Sample preparation and TEM}

After HPF, cryo-substitution took place in a LEICA EM AFS (Leica Microsystems, Vienna, Austria) freeze substitution device. Samples were submersed in cold acetone $\left(-80{ }^{\circ} \mathrm{C}\right)$ containing $2 \%$ osmium tetroxide and $0.05 \%$ uranyl acetate for $60 \mathrm{~h}$. After this time the temperature was slowly $\left(+10{ }^{\circ} \mathrm{C} \cdot \mathrm{h}^{-1}\right)$ increased to $-30{ }^{\circ} \mathrm{C}$, which was held constant for $4 \mathrm{~h}$. Finally warming-up $\left(+2.5{ }^{\circ} \mathrm{C}^{\cdot} \mathrm{h}^{-1}\right)$ was continued to $+20{ }^{\circ} \mathrm{C}$. After washing with pure acetone and propylene oxide the samples were embedded into epoxy resin (medium grade; Agar Scientific, Essex, UK) and polymerized $\left(+70{ }^{\circ} \mathrm{C}\right.$, $24 \mathrm{~h})$. Then ultra-thin sections $(70 \mathrm{~nm})$ were prepared by an EM UC7 ultramicrotome (Leica Microsystems, Vienna, Austria) [47, 50, 85]. Micrographs were taken in a LEO 912 AB Omega transmission electron microscope (Zeiss, Oberkochen, Germany) equipped with an in-column energy filter and operated with $\mathrm{a} \mathrm{LaB}_{6}$ cathode at $80 \mathrm{kV}$. Micrographs were filtered at zero energy loss. Images were captured by a CCD slow scan camera (TRS Sharpeye, Troendle, Moorenweis, Germany) and controlled by iTEM 5.0 software (Olympus SIS, Münster, Germany).

\section{Supplementary information}

Supplementary information accompanies this paper at https://doi. org/10.1186/s13007-020-00586-5.

Additional file 1: Figure S1. Pressurization and cooling rate during high pressure freezing of already frozen samples of $M$. denticulata $\left(-2^{\circ} \mathrm{C}\right)$ and R. glacialis $\left(-5^{\circ} \mathrm{C}\right)$.

Additional file 2: Figure S2. Preparation of leaf sections from Pinus mugo for high pressure freezing.

Additional file 3: Figure S3. Virtual front-end of the T-control software.

\section{Abbreviations}

AFU: Automatic freezing unit; GA: Glutaraldehyde; EDX: Energy-dispersive $X$-ray spectroscopy; EELS: Electron energy loss spectroscopy; ET: Electron tomography; FIB-SEM: Focused ion beam-scanning electron microscopy; HPF: High pressure freezing; INA: Ice nucleating active; MCH: Methyl cyclohexane; PD: Precooling device; PWM: Pulse-with modulation; PPFD: Photosynthetic Photon Flux Density; TEM: Transmission electron microscopy; TMA: Temperature measurement adapter.

\section{Acknowledgements}

We are grateful to the Austrian Science Fund for supporting the study (P30139). Further, we would like to express our gratitude to our technician Walter Gigerl, University of Salzburg who supported us with valuable ideas and built all necessary mechanical components. We also thank Tanja Schäfernolte, University of Innsbruck who helped us collecting $R$. glacialis plants and preparing related frost resistance test.

\section{Authors' contributions}

$\mathrm{OB}$ built the temperature control, designed the related T-control software and wrote the draft manuscript. OB, PS and AA together designed necessary technical equipment, developed and tested the work flow. PS did all HPF preparations of the frozen samples and most TEM evaluations. MS conducted vitality tests on R. glacialis and P. mugo and provided in situ leaf temperature data. AH contributed the $K$. crenulatum samples and evaluated the results of this organism. PS, AA and OB prepared the samples and took the TEM micrographs. All authors provided ideas and valuable input and contributed to final editing of the manuscript. GN and UL-M supervised this study. All authors read and approved the final manuscript.

\section{Funding}

The study was funded by the Austrian Science Fund (FWF), project "Ice management and freeze dehydration of plant cells" (P30139) to G. Neuner.

\section{Availability of data and materials}

All data generated or analysed during this study are included in this published article and its additional files.

\section{Ethics approval and consent to participate}

Not applicable.

\section{Consent for publication}

All authors have given consent for the publication of the manuscript. The authors assume no liability regarding the introduced methods. Its application takes place at the user's own risk.

\section{Competing interests}

The authors declare that they have no competing interests.

\section{Author details}

${ }^{1}$ Department of Biosciences, University of Salzburg, Hellbrunnerstrasse 34, 5020 Salzburg, Austria. ${ }^{2}$ Department of Botany, University of Innsbruck, Sternwartestrasse 15, 6020 Innsbruck, Austria.

Received: 10 January 2020 Accepted: 23 March 2020

Published online: 07 April 2020

\section{References}

1. Sakai A, Larcher W, Lange OL, Olson JS, Remmert H. Frost survival of plants. Responses and adaptation to freezing stress. In: Billings WD, Golley F, editors. Ecological studies, vol. 62. Berlin, Heidelberg, New York, London, Paris, Tokyo: Springer; 1987. https://doi.org/10.1007/978-3-642-71745-1.

2. Pearce R. Plant freezing and damage. Ann Bot. 2001;87:417-24. https:// doi.org/10.1006/anbo.2000.1352.

3. Kuprian E, Briceño VF, Wagner J, Neuner G. Ice barriers promote supercooling and prevent frost injury in reproductive buds, flowers and fruits of alpine dwarf shrubs throughout the summer. Environ Exp Bot. 2014;106:4-12.

4. Wisniewski M, Gusta L, Neuner G. Adaptive mechanisms of freeze avoidance in plants: a brief update. Environ Exp Bot. 2014;99:133-40. https:// doi.org/10.1016/j.envexpbot.2013.11.011.

5. Yadav SK. Cold stress tolerance mechanisms in plants. A review. Agron Sustain Dev. 2010:30:515-27. https://doi.org/10.1051/agro/2009050.

6. Hincha DK, Zuther E. Plant cold acclimation and freezing tolerance. In: Hincha DK, Zuther E, editors. Plant cold acclimation. New York: Springer; 2014. p. 1-6. https://doi.org/10.1007/978-1-4939-0844-8_1.

7. Levitt J. Responses of plants to environmental stresses. 1st ed. New York: Academic Press; 1972. p. 697. ISBN 978-0124455603.

8. Arora R. Mechanism of freeze-thaw injury and recovery: a cool retrospective and warming up to new ideas. Plant Sci. 2018;270:301-13. https:// doi.org/10.1016/j.plantsci.2018.03.002.

9. Mazur P. Kinetics of water loss from cells at subzero temperatures and the likelihood of intracellular freezing. J Gen Physiol. 1963;47(2):347-69. https ://doi.org/10.1085/jgp.47.2.347. 
10. Rajashekar CB, Burke M. Liquid water during slow freezing based on cell water relations and limited experimental testing. In: Li PH, Sakai A, editors. Plant cold hardiness and freezing stress: mechanisms and crop implications, vol. 2. New York: Academic Press; 1982. p. 211-20. https:// doi.org/10.1016/B978-0-12-447602-8.X5001-6.

11. Steponkus PL, Webb. Freeze-induced dehydration and membrane destabilization in plants. In: Somero GN, Osmond CB, Bolis CL, editors. Water and life. Berlin, Heidelberg: Springer; 1992. p. 338-62. https://doi. org/10.1007/978-3-642-76682-4_20.

12. Rajashekar CB, Burke MJ. Freezing characteristics of rigid plant tissues (development of cell tension during extracellular freezing). Plant Physiol. 1996;111:597-603.

13. Buchner $O$, Neuner G. Freezing cytorrhysis and critical temperature thresholds for photosystem II in the peat moss Sphagnum capillifolium. Protoplasma. 2010;243:63-71. https://doi.org/10.1007/s0070 9-009-0053-8.

14. Wisniewski M, Bassett C, Gusta LV. An Overview of cold hardiness in woody plants: seeing the forest through the trees. HortScience. 2003;38:952-9.

15. Gusta LV, Wisniewski M. Understanding plant cold hardiness: an opinion. Physiol Plantarum. 2013;147:4-14. https://doi.org/10.111 1/j.1399-3054.2012.01611.x

16. Gupta R, Deswal R. Antifreeze proteins enable plants to survive in freezing conditions. J Biosci. 2014;39:931-44. https://doi.org/10.1007/s1203 8-014-9468-2.

17. Asahina E. The freezing process of plant cell. Contributions from the Institute of Low Temperature Science 1956;10:83-126. http://hdl.handl e.net/2115/20219.

18. Niki T. Ultrastructural change of plasma membrane in cortical parenchyma cells of mulberry twig related to freezing tolerance. In: Li PH, Sakai A, editors. Plant cold hardiness and freezing stress: mechanisms and crop implications, vol. 2. New York: Academic press; 1982. p. 189-97. https:// doi.org/10.1016/B978-0-12-447602-8.X5001-6.

19. Yamazaki T, Kawamura Y, Uemura M. Cryobehavior of the plasma membrane in protoplasts isolated from cold-acclimated Arabidopsis leaves is related to surface area regulation. Plant Cell Physiol. 2008;49:944-57. https://doi.org/10.1093/pcp/pcn068.

20. Lancelle SA, Hepler PK. Cytochalasin-induced ultrastructural alterations in Nicotiana pollen tubes. In: Tazawa M, editor. Cell dynamics: molecular aspects of cell motility cytoskeleton in cellular structure and activity. Vienna: Springer; 1989. p. 65-75. https://doi. org/10.1007/978-3-7091-9011-1_8.

21. Hepler PK, Palevitz BA, Lancelle SA, McCauley MM, Lichtscheidl I. Cortical endoplasmic reticulum in plants. J Cell Sci. 1990;96:355-73.

22. Kiss JZ, Giddings TH, Staehelin LA, Sack FD. Comparison of the ultrastructure of conventionally fixed and high pressure frozen/freeze substituted root tips of Nicotiana and Arabidopsis. Protoplasma. 1990;157:64-74. https ://doi.org/10.1007/BF01322639.

23. Lancelle SA, Hepler PK. Ultrastructure of freeze-substituted pollen tubes of Lilium longiflorum. Protoplasma. 1992;167:215-30. https://doi. org/10.1007/BF01403385.

24. Staehelin LA, Hepler PK. Cytokinesis in higher plants. Cell. 1996. https:// doi.org/10.1016/S0092-8674(00)81060-0.

25. Roy S, Eckard KJ, Lancelle S, Hepler PK, Lord EM. High-pressure freezing improves the ultrastructural preservation of in vivo grown lily pollen tubes. Protoplasma. 1997;200:87-98. https://doi.org/10.1007/BF01280737

26. Bourett TM, Czymmek KJ, Howard RJ. Ultrastructure of chloroplast protuberances in rice leaves preserved by high-pressure freezing. Planta. 1999;208:472-9. https://doi.org/10.1007/s004250050584.

27. Studer D, Humbel BM, Chiquet M. Electron microscopy of high pressure frozen samples: bridging the gap between cellular ultrastructure and atomic resolution. Histochem Cell Biol. 2008;130:877-89. https://doi. org/10.1007/s00418-008-0500-1.

28. Wang P, Liang Z, Kang B. Electron tomography of plant organelles and the outlook for correlative microscopic approaches. New Phytol. 2019;223:1756-61. https://doi.org/10.1111/nph.15882.

29. Dubochet J. The physics of rapid cooling and its implications for cryoimmobilization of cells. Method Cell Biol. 2007;79:7-21. https://doi. org/10.1016/S0091-679X(06)79001-X.
30. Brüggeller P, Mayer E. Complete vitrification in pure liquid water and dilute aqueous solutions. Nature. 1980;288:569-71. https://doi. org/10.1038/288569a0.

31. Franks F. The properties of aqueous solutions at subzero temperatures. In: Franks F, editor. Water and aqueous solutions at subzero temperatures. 338: 215; 1982. https://doi.org/10.1007/978-1-4757-6952-4_3.

32. Moor $\mathrm{H}$. Theory and practice of high pressure freezing. In: Steinbrecht RA, Zierold K, editors. Cryotechniques in biological electron microscopy. Berlin, Heidelberg: Springer; 1987. p. 175-91. https://doi.org/10.1007/978-3642-72815-0_8

33. Debenedetti PG, Stanley HE. Supercooled and glassy water. Phys Today. 2003;56:40-6. https://doi.org/10.1063/1.1595053.

34. Richter K. High-density morphologies of ice in high-pressure frozen biological specimens. Ultramicroscopy. 1994;53:237-49. https://doi. org/10.1016/0304-3991(94)90037-X.

35. Dubochet J. High-pressure freezing for cryoelectron microscopy. Trends Cell Biol. 1995;5:366-8. https://doi.org/10.1016/S0962-8924(00)89071-6.

36. Edebo L, Hedén C-G. Disruption of frozen bacteria as a consequence of changes in the crystal structure of ice. J Biochem Microbiol. 1960;2:11320. https://doi.org/10.1002/jbmte.390020110.

37. Lütz-Meindl U. Micrasterias as a model system in plant cell biology. Front Plant Sci. 2016:7:999. https://doi.org/10.3389/fpls.2016.00999.

38. Holzinger A, Lütz C, Karsten U. Desiccation stress causes structural and ultrastructural alterations in the aeroterrestrical green alga Klebsormidium crenulatum (Klebsormidiophyceae, Streptophyta) isolated from an alpine soil crust. J Phycol. 2011;47:591-602. https://doi.org/10.111 1/j.1529-8817.2011.00980.x.

39. Kaplan F, Lewis LA, Wastian J, Holzinger A. Plasmolysis effects and osmotic potential of two phylogenetically distinct alpine strains of Klebsormidium (Streptophyta). Protoplasma. 2012;249:789-804. https://doi.org/10.1007/ s00709-011-0324-z.

40. Basile A, Sorbo S, Cardi M, Lentini M, Castiglia D, Cianciullo P, et al. Effects of heavy metals on ultrastructure and Hsp70 induction in Lemna minor L. exposed to water along the Sarno River. Italy. Ecotox Environ Safe. 2015;114:93-101. https://doi.org/10.1016/j.ecoenv.2015.01.009.

41. Appenroth K-J, Sree KS, Böhm V, Hammann S, Vetter W, Leiterer M, et al. Nutritional value of duckweeds (Lemnaceae) as human food. Food Chem. 2017:217:266-73. https://doi.org/10.1016/j.foodchem.2016.08.116.

42. Steiner P, Luckner M, Kerschbaum H, Wanner G, Lütz-Meindl U. Ionic stress induces fusion of mitochondria to 3-D networks: an electron tomography study. J Struct Biol. 2018;204:52-63. https://doi.org/10.1016/j. jsb.2018.06.010.

43. Lütz C. Cytology of high alpine plants II. Microbody activity in leaves of Ranunculus glacialis L. Cytologia. 1987:52:679-86. https://doi.org/10.1508/ cytologia.52.679.

44. Wagner J, Steinacher G, Ladinig U. Ranunculus glacialis L.: successful reproduction at the altitudinal limits of higher plant life. Protoplasma. 2010;243:117-28. https://doi.org/10.1007/s00709-009-0104-1.

45. Neuner G, Buchner O. Assessment of foliar frost damage: a comparison of in vivo chlorophyll fluorescence with other viability assays. J Appl Bot. 1999;73:50-4.

46. Dahl R, Staehelin LA. High-pressure freezing for the preservation of biological structure: theory and practice. J Electron Microbiol Tech. 1989;13:165-74. https://doi.org/10.1002/jemt.1060130305.

47. Meindl U, Lancelle S, Hepler PK. Vesicle production and fusion during lobe formation in Micrasterias visualized by high-pressure freeze fixation. Protoplasma. 1992;170:104-14. https://doi.org/10.1007/BF01378786.

48. Lütz-Meindl U, Brosch-Salomon S. Cell wall secretion in the green alga Micrasterias. J Microsc. 2000;198:208-17. https://doi.org/10.104 6/j.1365-2818.2000.00699.x.

49. Affenzeller MJ, Darehshouri A, Andosch A, Lütz C, Lütz-Meindl U. Salt stress-induced cell death in the unicellular green alga Micrasterias denticulata. J Exp Bot. 2009;60:939-54. https://doi.org/10.1093/jxb/ern348.

50. Andosch A, Affenzeller MJ, Lütz C, Lütz-Meindl U. A freshwater green alga under cadmium stress: ameliorating calcium effects on ultrastructure and photosynthesis in the unicellular model Micrasterias. J Plant Physiol. 2012;169:1489-500. https://doi.org/10.1016/j.jplph.2012.06.002.

51. Volland S, Lütz C, Michalke B, Lütz-Meindl U. Intracellular chromium localization and cell physiological response in the unicellular alga Micrasterias. Aquat Toxicol. 2012;109:5-69. https://doi.org/10.1016/j.aquat ox.2011.11.013. 
52. Schwarz V, Andosch A, Geretschläger A, Affenzeller M, Lütz-Meindl U. Carbon starvation induces lipid degradation via autophagy in the model alga Micrasterias. J Plant Physiol. 2017;208:115-27. https://doi. org/10.1016/j.jplph.2016.11.008.

53. Lütz C, Moser W. On the cytology of high alpine plants: I. The ultrastructure of Ranunculus glacialis L. Flora. 1977;166:21-34. https://doi. org/10.1016/S0367-2530(17)32107-2.

54. Kivimäenpää M, Sutinen S. Microscopic structure of Scots pine (Pinus sylvestris (L.)) needles during ageing and autumnal senescence. Trees. 2007;21:645-59. https://doi.org/10.1007/s00468-007-0157-8.

55. Moser T, Holzinger A, Buchner O. Chloroplast protrusions in leaves of Ranunculus glacialis L. respond significantly to different ambient conditions, but are not related to temperature stress. Plant Cell Environ. 2015;38:1347-56. https://doi.org/10.1111/pce.12483.

56. Kukkola E, Huttunen S, Bäck J, Rautio P. Scots pine needle injuries at subarctic industrial sites. Trees. 1997;11(6):378-87. https://doi.org/10.1007/ s004680050099.

57. Zellnig G, Gailhofer M, Pfeifhofer HW, Grill D. Ultrastructure and pigment composition of chloroplasts of differently damaged green and yellowed needles of Picea abies. Phyton Annales Rei Botanicae. 1989;29(2): 213-25. https://www.zobodat.at/pdf/PHY_29_2_0213-0225.

58. Jiménez MS, Zellnig G, Stabentheiner E, Peters J, Morales D, Grill D. Structure and ultrastructure of Pinus canariensis needles. Flora. 2000;195:22835. https://doi.org/10.1016/S0367-2530(17)30975-1.

59. Zechmann B, Zellnig G. Microwave-assisted rapid plant sample preparation for transmission electron microscopy. J Microsc. 2009;233:258-68. https://doi.org/10.1111/j.1365-2818.2009.03116.x.

60. Samuels A, Rensing K, Douglas C, Mansfield S, Dharmawardhana D, Ellis B. Cellular machinery of wood production: differentiation of secondary xylem in Pinus contorta var. latifolia. Planta. 2002;216:72-82. https://doi. org/10.1007/s00425-002-0884-4

61. Rensing KH, Samuels AL. Cellular changes associated with rest and quiescence in winter-dormant vascular cambium of Pinus contorta. Trees. 2004;18(4):373-80. https://doi.org/10.1007/s00468-003-0314-7.

62. Kaech A, Ziegler U. High-pressure freezing: current state and future prospects. In: Kuo J, editor. Electron microscopy. Methods in molecular biology (methods and protocols). Totowa: Humana Press; 2014. https:// doi.org/10.1007/978-1-62703-776-1_8.

63. Yakovlev S, Downing KH. Crystalline ice as a cryoprotectant: theoretical calculation of cooling speed in capillary tubes. J Microsc. 2011;243:8-14 https://doi.org/10.1111/j.1365-2818.2011.03498.x.

64. Chaplin M. Water structure and science. http://www1.Isbu.ac.uk/water/ water_phase_diagram.html\#intr2. Accessed 8 Jan 2020.

65. Kanno H, Speedy RJ, Angell CA. Supercooling of water to $-92{ }^{\circ} \mathrm{C}$ under pressure. Science. 1975;189(4206):880-1. https://doi.org/10.1126/scien ce.189.4206.880.

66. Mishima O, Calvert LD, Whalley E. 'Melting ice'I at $77 \mathrm{~K}$ and $10 \mathrm{kbar}$ : a new method of making amorphous solids. Nature. 1984;310:393-5. https:// doi.org/10.1038/310393a0.

67. Mishima O. Relationship between melting and amorphization of ice. Nature. 1996:384:546-9. https://doi.org/10.1038/384546a0.

68. Bauer M, Elsaesser MS, Winkel K, Mayer E, Loerting T. Compression-rate dependence of the phase transition from hexagonal ice to ice II and/ or ice III. Phys Rev B. 2008;77(22):1-4. https://doi.org/10.1103/PhysR evB.77.220105.

69. Brook AJ. The biology of Demids. Botanical monographs, vol. 16. Oakland: University of California Press; 1981.

70. Kiermayer O. Cytoplasmic basis of morphogenesis in Micrasterias. In: Kiermayer O, editor. Cytomorphogenesis in plants. Vienna: Springer; 1981. p. 147-89. https://doi.org/10.1007/978-3-7091-8602-2_6.

71. Meindl U. Micrasterias cells as a model system for research on morphogenesis. Microbiol Rev. 1993;57:415-33 (PMID: 7687738)
72. Schlösser UG. Sammlung von Algenkulturen. Ber Deutsch Bot Ges. 1982;95:181-276. https://doi.org/10.1111/j.1438-8677.1982.tb02862.x.

73. Starr RC, Zeikus JA. UTEX-the culture collection of algae at the university of Texas at Austin. J Phycol. 1993;29:1-106. https://doi.org/10.111 1/j.0022-3646.1993.00001.x.

74. Radić S, Stipaničev D, Cvjetko P, Marijanović Rajčić M, Širac S, PevalekKozlina B, et al. Duckweed Lemna minor as a tool for testing toxicity and genotoxicity of surface waters. Ecotoxicol Environ Saf. 2011;74:182-7. https://doi.org/10.1016/j.ecoenv.2010.06.011.

75. Cowgill U, Milazzo D. The culturing and testing of two species of duckweed. In: Cowgill U, Williams L, editors. Aquatic toxicology and environmental fate. West Conshohocken: ASTM International; 1989. p. 379-91. https://doi.org/10.1520/STP16825S.

76. Richarz K, Kremer BP. Organismische Rekorde. Berlin, Heidelberg: Springer; 2017. p. 99-176. https://doi.org/10.1007/978-3-662-53780-0.

77. Larcher W, Wagner J, Lütz C. The effect of heat on photosynthesis, dark respiration and cellular ultrastructure of the arctic-alpine psychrophyte Ranunculus glacialis. Photosynthetica. 1998;34:219-32. https://doi. org/10.1016/j.envexpbot.2014.01.011.

78. Buchner $\mathrm{O}$, Lütz C, Holzinger A. Design and construction of a new temperature-controlled chamber for light and confocal microscopy under monitored conditions: biological application for plant samples. J Microsc. 2007;225:183-91.

79. Neuner G, Huber B, Plangger A, Pohlin J-M, Walde J. Low temperatures at higher elevations require plants to exhibit increased freezing resistance throughout the summer months. Env Exp Bot. 2020. https://doi. org/10.1016/j.envexpbot.2019.103882.

80. Šabacká M, Elster J. Response of cyanobacteria and algae from Antarctic wetland habitats to freezing and desiccation stress. Polar Biol. 2006;30:31-7. https://doi.org/10.1007/s00300-006-0156-z.

81. Nagao M, Matsui K, Uemura M. Klebsormidium flaccidum, a charophycean green alga, exhibits cold acclimation that is closely associated with compatible solute accumulation and ultrastructural changes. Plant Cell Environ. 2008;31:872-85.

82. Neuner G, Hacker J. Ice formation and propagation in Alpine plants. In: Lütz C, editor. Plants in alpine regions. Berlin: Springer; 2012. https://doi. org/10.1007/978-3-7091-0136-0_12.

83. Studer D, Graber W, Al-Amoudi A, Eggli P. A new approach for cryofixation by high-pressure freezing. J Microsc. 2001;203:285-94 (PMID: 11555146).

84. Studer D, Michel M, Müller M. High pressure freezing comes of age. Scanning Microsc Suppl. 1989;3:253-68 (PMID: 2694271).

85. Lütz-Meindl U, Aichinger N. Use of energy-filtering transmission electron microscopy for routine ultrastructural analysis of high-pressure-frozen or chemically fixed plant cells. Protoplasma. 2004;22(2-4):155-62. https:// doi.org/10.1007/s00709-003-0033-3.

\section{Publisher's Note}

Springer Nature remains neutral with regard to jurisdictional claims in published maps and institutional affiliations.

Ready to submit your research? Choose BMC and benefit from:

- fast, convenient online submission

- thorough peer review by experienced researchers in your field

- rapid publication on acceptance

- support for research data, including large and complex data types

- gold Open Access which fosters wider collaboration and increased citations

- maximum visibility for your research: over 100M website views per year

At BMC, research is always in progress.

Learn more biomedcentral.com/submissions 